\title{
The Effect of Exchange Rate and Interest Rate Volatilities on Stock Prices: Further Empirical Evidence from Ghana
}

\author{
Grace Ofori-Abebrese (i) ${ }^{1}$ Samuel Tawiah Baidoo (ib ${ }^{2}$ \\ Peter YaW OSEI (1) ${ }^{3}$
}

Received: 25.10.2019; Revised: 29.11.2019; Accepted: 20.12.2019

\begin{abstract}
Studies have proven that volatilities in the rates of exchange and interest influence the performance of institutions and the values of their shares. This study investigates empirically the effect of exchange rate and interest rate volatilities on stock prices of financial institutions listed on the Ghana Stock Exchange using monthly data spanning the period January 2000 to October 2016. The generalized autoregressive conditional heteroskedastic (GARCH) model is employed for the analysis. The results show that exchange rate volatility exerts a positive effect on stock prices whereas interest rate volatility impacts on stock prices negatively. These results imply that the trade-off between risk and return can be predicted so industry players and stakeholders can manage risk to ensure a vibrant financial market. It is also suggested that there is a need for stakeholders and policymakers to ensure that these variables are stable or the volatilities are minimized in the economy. This will go a long way to enhance the performance of the stock market activities in the country.
\end{abstract}

JEL codes: C32, E30, E44, G10

Keywords: Exchange rate, stock prices, volatility, financial markets, GARCH model

\section{Introduction}

External factors such as government regulations, the general business conditions, conditions in the money and capital markets and the tax structure in an economy inter-

\footnotetext{
${ }^{1}$ Department of Economics, Kwame Nkrumah University of Science and Technology, Kumasi, Ghana (e-mail: ofori35@yahoo.com).

2 Corresponding Author: Department of Economics, Kwame Nkrumah University of Science and Technology, Kumasi, Ghana (e-mail: samueltawiahbaidoo@yahoo.com).

${ }^{3}$ Republic Bank Investments, Accra, Ghana (e-mail: peyasei@gmail.com).
}

play to influence managerial decisions which ultimately affect share prices. These external factors directly feed into the strategy and policy decisions controlled by management of firms with regard to which products/services to offer, the marketing and production systems to adopt, capital structure choices and the investment policy to adopt, among others. These decisions, in turn, affect the size and timing of cash flows from investments and the risks associated with such cash flows. This linkage thus hammer home that conditions in the macroeconomy is of great relevance to firms. Two of such 
macroeconomic variables businesses require to effectively plan are the rates of exchange and interest (see, for instance, Caporale \& Gil-Alana, 2016). Hyde (2007) explained that the risks associated with these two economic variables constitute an important effect on common stocks.

It is asserted that financial sector liberalization and advances in the application of technology in the financial sector have stirred up the interaction amid exchange rate, interest rate and stock returns thereby increasing research activity in this area over the years (Mouna \& Anis, 2016). Further, it is documented that fluctuations in exchange rate pose threats to general price levels, the profitability of firms and the stability of the general macroeconomy (Benita \& Lauterbach, 2007). Such fluctuations also have consequences on the financial market as a whole and the stock market in particular (Opoku-Agyemang et al., 2016).

The connections between interest rate, exchange rate and profits of firms remain a vital concern for risk and portfolio management in the financial sector. Foreign exchange transactions constitute a significant aspect of the business of financial institutions. Most commercial banks operate in the local inter-bank foreign exchange market. Banks also function as facilitators of international trade by establishing letters of credit to importers and other related roles. The facilitation role, therefore, exposes these financial institutions to a significant foreign exchange risk as volatilities affect planning and returns (see, for example, Zhao, 2010; Okpara \& Odionye, 2012; Suriani et al., 2015).

Financial sector returns are particularly sensitive to interest rate volatility due to the environment within which the banking sector operates. Fluctuations in the rate of interest significantly influence the cost of financing as well as the value of liabilities and assets owned by financial corporations. Given limited resources, the rising interest rate on government securities increases the demand for such securities and these higher yields affect how much deposit customers place with banks. Lower deposits also significantly affect the size of loans banks can advance. Interest income constituting the biggest revenue to financial institutions and thus diminished loan portfolios reduces returns on financial stocks.

Though empirical studies exist on the subject matter, the results have been inconclusive. Whilst some have found negative and positive relationships, others have reported no relationship. For instance, an inverse relationship between prices of stocks and the rate of interest has been established (see, for example, Alam \& Uddin, 2009; Okpara \& Odionye, 2012). With regard to the influence of rate of exchange on prices of stock, a study by Franck and Young (1972) established no relationship. Contrary to this, a study by Aggarwal (2003) reported a positive relationship while Olugbenga (2012) revealed a long run negative relationship. In the case of Ghana, C. Adjasi et al. (2008) established an inverse relationship between volatility of exchange rate and stock returns. Addo and Sunzuoye (2013) also established a negative relationship between interest rates and stock returns. Therefore, the differences in results make further studies a worthwhile task.

It must also be emphasized that the studies on Ghana by C. Adjasi et al. (2008) and Addo and Sunzuoye (2013) examined the impact of these two economic variables on stock returns in isolation. Further, these studies focused on the broad market index (the composite index) but it can be argued that rates of interest and exchange affect an economy as a whole but their influence is varied across sectors and industries. A disaggregation analysis of financial stocks (banks, financial service and insurance firms) is therefore appropriate because market aggregation (as in the broad index) may not reveal significant differences between the financial sector and other sectors in terms of interest rate and exchange rate sensitivity 
(Mouna \& Anis, 2016). In the light of this argument, since the stocks of financial institutions have the largest representation on the Ghana Stock Exchange (GSE), and fluctuations in the listed indicators have a more direct effect on their performance and profitability, this study seeks to examine the effects of volatilities of both interest and exchange rates on the prices of financial stocks listed (GSE-FI) on the GSE.

The study makes some contributions to knowledge and literature with regard to the effect of exchange and interest rates on stock prices. First, the study would aid potential investors in understanding whether volatilities of these variables affect prices of financial stocks differently from how it affects the entire market thereby informing their investment choices under various scenarios of the rate of interest and exchange rate conditions that may prevail in the market. Second, the findings of this study will also inform managers of financial institutions and other firms the actions to take in order to mitigate some of the adverse effects of excessive volatility in these variables and also to take advantage of anticipated and unanticipated changes in the future.

The paper proceeds as follows. Section 2 presents the literature review whereas section 3 focuses on the empirical methodology. Section 4 is devoted to results and discussion whilst the section 5 presents the concluding remarks of the study.

\section{Literature review}

This section provides the theoretical underpinnings as well as the review of past studies which form the basis for the study.

Some of the theories and models related to exchange rate determination are the Purchasing Power Parity (PPP), Sticky Price Monetary (SPM), Flexible Price Monetary (FPM) and the Real Interest Rate Differential (RIRD). According to the theory of PPP, parity among local prices and overseas prices calculated in the local currency through commodity arbitrage is maintained. Should there be a violation in the equilibrium condition, the same commodity in the wake of altering rate of exchange would be sold at various prices in various nations. Accordingly, buying of commodities simultaneously within a least priced nation and selling in a high priced country would convey back the exchange rate to its equilibrium level.

In determining the rate of exchange, the SPM, RIRD as well as the FPM are classified as the monetarists' model. The forces of demand for money and the supply of money are essential determining factors of exchange rate. They presume that local and overseas bonds are similarly risky hence their expected returns would be made equal. Supposing that wages and prices in the labour and goods markets respectively are perfectly flexible, for the theory of PPP to hold constantly as well as expected returns amid local and overseas bonds with equal risk and maturity being equivalent, the FPM contends that the relative supply of money, inflationary expectations and economic growth are key determining factors of the rate of exchange within a country. The SPM proposed by Dornbusch (1976) contends that prices and wages during the short term have a tendency of being inflexible, hence the yearning of investors to make equal expected returns across countries is seen as the major determining factor of exchange rates, while goods market arbitrage is seen as relevant to exchange rate determination in the medium and long term. Frankel (1979) put forward an exchange rate model known as the real interest rate differential, which incorporates the role of inflationary expectations of the FPM as well as sticky prices model of exchange rate determination. Thus, the spot exchange rate may be positively influenced by high interest rate policy when the expected exchange rate becomes an increasing function of the domestic interest rates. Sargent and Wallace (1981) 
indicate that an increment in government debt, may raise interest rate and prompt a decline in the demand for money which will depreciate the exchange rate. Furman et al. (1998) also argue that a rise in interest rate may negatively influence the future export performance which would cause a fall in the future flow of foreign exchange reserves and hence resulting in currency depreciation subsequently.

Furman et al. (1998) further highlight on two imperative channels through which exchange rates could probably be influenced by interest rates increments. One such channel is the risk of default and the other is the risk premium. Since the uncovered interest rate parity theory assumes no role for both of these channels, the interest rate represents the promised return on domestic assets. Therefore, actual interest receipts equal promised interest receipts. Be that as it may, in a post emergency circumstance, high interest rate policy may diminish the likelihood of reimbursement and cause a rise in the risk premium on domestic assets in light of its negative impact on domestic economic activity by decreasing the benefit of local firms and expanding the costs of borrowing. In this manner, a rise in interest rate may prompt depreciation of the exchange rate. This could be stronger when the financial position of firms and banks is delicate.

To theoretically analyze the influences that exchange rate and interest rate volatilities have on stock prices, reference is made to the work of Aurangzeb and Khola (2012) who observed the stock market as the standard of measuring the economic health of a country. This is because several financial and other macroeconomic variables affect the stock market performance of a country. One of the unique variables of interest to both investors and policymakers is the rate of exchange due to the effects of its volatility on both internal and international financial transactions of the country.

The Flow Oriented Model upholds that there is a causal linkage between the rate of exchange and prices of stocks running from the former to the latter. Joseph (2002) adds that fluctuations in rate of exchange influence the competitiveness of businesses through their effect on prices of inputs and outputs. Consequently, currency appreciation causes goods and services on the international market to be overpriced. This decreases global competitiveness and profits of firms in the export sector. Accordingly, stock prices of such institutions lose competitiveness on the local stock market. Therefore, an inverse relationship can be established between domestic currency and stock prices. C. K. Adjasi and Biekpe (2005) believe that in the Stock Oriented Model, exchange rate equates demand and supply for assets. Hence, expectations of relative currency movements have a substantial effect on price movements of financially held assets. As a result, fluctuation in the currency may impact on stock price movements.

The Arbitrage Pricing Theory (APT) multi-factor models have turned out to be extremely prominent in asset pricing. Chen et al. (1986) and Iqbal and Haider (2005) contend that factors of risks in the APT emerge from changes in some basic financial and economic variables such as inflation, interest rates and exchange rate. Interest rate in finance could be explained as a measurement of time value of money and as such one of the determining factors of stock prices. Subsequently, any variations in interest rate can cause trouble for investors and possibly influence a firm's profitability and thus fluctuating stock prices. Based on the APT theory, Rashid (2007) explains that increment in real interest rates causes a reduction in the present value of a company's future cash flows resulting in a decline in stock prices. In addition, a high rate of interest invigorates the capital inflow and subsequently appreciates the exchange rate. Theories linking stock prices and exchange rates are the traditional theory and portfolio 
adjustments approach. According to the traditional theory, depreciation of a currency increases exports and accrue higher profits to companies, thereby raising their stock prices within the short term. Thus depreciation improves competitiveness of businesses, which modifies the value of liabilities and assets of companies and hence profits which are reflected in stock prices (Solnik, 1987). Alternatively, Solnik (1987) explains that if firms depend mainly on imported inputs, depreciation will increase their production cost and decrease their profitability as well as their stock prices.

The portfolio adjustments approach posits that movements in capital flows cause changes in prices of stock. Solnik (1987) illustrates that a fall in the prices of stock signifies a reduction in corporate wealth. This leads to a fall in demand for domestic currency and a fall in interest rates as a corrective measure from the monetary authorities. The relative low interest rates initiate capital outflow which depreciates the domestic currency. Alam and Uddin (2009) add that there is a directional impact from interest rate to financial market. According to the study, increases in interest rates incite investors to change their investments structures, mostly from capital market to fixed income securities. This is due to the fact that, stocks are very responsive to rates of interest, since fluctuations in the rate and stocks are contrariwise linked.

On the empirical front, some studies have also been conducted to investigate the effect of exchange rate and interest rate on stock prices. Using both daily and monthly data from the period 1990 to 1997, Mathieson and Moles (1998) investigate the economic currency risk and company value of UKlisted importing and exporting firms. Their results indicate that individual firms have different exposures to particular currencies. Using daily data, the study reveals that 11 out of 31 importing firms and 9 out of 32 exporting firms are sensitive to exchange rate changes. Further, the analysis with the monthly data shows that 2 and 4 out of 31 and 32 importing and exporting firms respectively are sensitive to exchange rate changes. Additionally, using the GARCH $(1,1)$ approach, the authors find a weak relationship between the share price of the firms and exchange rates exposure.

Further, Samarakoon et al. (1999) investigate the effect of interest rates measured by the Treasury bill rates on stock prices of Sri Lanka stock market. The study employs two measures for stock prices, namely, the All Share Prices Index and Sensitive Price Index. Using daily data from January 1985 to December 1995, the study employs feasible (or estimated) generalized least squares (EGLS) as the estimation technique. The study reveals a positive relationship between interest rate and stock prices.

In a related study, Muhammad and Rasheed (2002) examine the relationship between stock prices and exchange rates in four Asian countries: Pakistan, India, Bangladesh and Sri Lanka. The study uses monthly data from January 1994 to December 2000 and employs cointegration, vector error correction model technique and the standard granger causality test for the analysis. The results indicate that there exit no short-run association between the variables for all the countries considered. Further, the granger causality test reveals a bidirectional long-run causality between the variables for Bangladesh and Sri-Lanka. Similarly, using daily data for the year 2004, Randal et al. (2008) examine the short term exchange rate exposure for New Zealand firms. The results from the augmented market model indicate that few firms were significantly exposed to exchange rate volatility.

C. Adjasi et al. (2008) examine the relationship between stock market returns and exchange rate using monthly data from March 1995 to June 2006. Employing the GARCH $(1,1)$ and EGARCH $(1,1)$ as estimation techniques, the study shows that there is a negative relationship between exchange rate, interest rate and stock prices. 
The results further reveal a positive relationship between inflation and stock prices. Also, Vaz et al. (2008) investigate the effect of announced interest rate on stock return of 51 major banks in Australia over the period January 1990 to June 2005. The study uses the augmented market model and reports that stock returns of Australian banks are not negatively affected by the announced increases in official interest rate.

In a related study, Aydemir and Demirhan (2009) examine the relationship between prices of stock and exchange rates in Turkey over the period 23rd February 2001 to 11th January 2008. The results from the vector autoregressive (VAR) and the Granger causality test reveal a bi-directional causal relationship between exchange rate and stock prices. Similarly, using monthly data from the period 2002 to 2003, Connelly et al. (2009) examine the exchange rate exposure for 68 insurance firms in Asia Pacific countries. The results show that there is a positive relationship between exchange rate exposure and stock returns.

Also, Kuwornu and Owusu-Nantwi (2011) examine the effect of macroeconomic variables such as exchange rate, interest rate and inflation on stock prices using full information maximum likelihood estimation technique. Monthly data from January 1992 to December 2008 is employed. The study shows that there is a negative relationship between exchange rate, interest rate and stock prices. Further, a positive relationship between inflation and stock prices is revealed. Using the vector error correction model, Addo and Sunzuoye (2013) investigate the effect of interest rate on stock returns for Ghana. The study uses monthly data from January 1995 to December 2011. The results reveal that there is a negative relationship between interest rate and stock returns. This negative result is consistent with the finding by Okpara and Odionye (2012) who examine the effect of interest rate on stock prices for Nigeria. In a related study on Nigeria, Olugbenga (2012) reveals

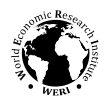

a positive relationship between exchange rate and stock performance using quarterly data from 1985 to 2009. The study employs the error correction model as an estimation technique.

Amarasinghe (2015) investigates the effect of interest rate on stock prices using evidence from Colombo Stock Exchange. The study uses monthly data from January 2007 to December 2013 and the results from the error correction model reveals a negative relationship between interest rate and stock prices which is consistent with the findings by Addo and Sunzuoye (2013) on Ghana and Haughton and Iglesias (2017) on Caribbean and Latin America. In a related study in Zambia, Sichoongwe (2016) investigates the effect of exchange rate volatility on stock market. The study uses annual time series data covering the period 2000 to 2015 and employs GARCH $(1,1)$ for the estimation. The study reveals a negative relationship between exchange rate volatility and stock market which is consistent with the study by Kwofie and Ansah (2018). Kwofie and Ansah (2018) examine the effect of inflation and exchange rate on stock market returns in Ghana using monthly data from January 2000 to December 2013. The results from the autoregressive distributed lag model show that there is a positive relationship between inflation and stock market returns and a negative relationship between exchange rate and stock market returns.

\section{Empirical methodology}

This section discusses the methodology the study adopts and it comprises model and estimation strategy, data and variable description.

\subsection{Model and estimation strategy}

In estimating the volatility of time series data, several models exist based on different distributional assumptions. The autoregressive conditional heteroscedasticity (ARCH) models are used to analyze volatilities in 
time series data (Engle, 2001), and most of these data are common in the financial domain. The present study makes use of financial data that exhibits non-constant variance over time and hence the $\mathrm{ARCH}$ model becomes an appropriate estimation technique. This is because, the non-constant variance indicates that the data suffers from heteroscedasticity.

Among the various autoregressive conditional heteroskedastic $(\mathrm{ARCH})$ models, the study adopts the generalized autoregressive conditional heteroskedastic (GARCH) $(1,1)$ model which is also used in some past studies (see for example, Zhao, 2010). The study chooses this model because it is the most fundamental and robust within the family of volatility models (Engle, 2001). Further, the GARCH model takes into account information on the stochastic process by which time varying variables are generated. The GARCH model is an extension of the ARCH model which was developed by Bollerslev et al. (1988). The study adopts the generalized form of $\mathrm{ARCH}$ (q) which is also known as the GARCH $(1,1)$ model based on the Gaussian normal distribution assumption proposed by Bollerslev et al. (1988).

A general GARCH model estimates both mean and variance equations where the ordinary least squares captures the mean equation and a constant is included in the variance equation. The $\mathrm{ARCH}$, as well as the GARCH terms, accounts for volatility. Both the mean and variance equations are jointly estimated using the Bollerslev and Wooldridge (1992) Quasi-maximum likelihood. The mean and the variance equations are specified in equations (1) and (2) respectively.

$$
\begin{gathered}
G S E A S I_{t}=\Phi_{0}+\Phi_{1} E X R_{t}+ \\
\Phi_{2} I N T R_{t}+\Phi_{3} I N F_{t}+\varepsilon_{t}
\end{gathered}
$$

where $\varepsilon_{t} \sim N\left(0, h_{t}\right)$

$$
h_{t}=\omega+\beta h_{t-1}+\alpha \varepsilon_{t-1}^{2}
$$

From equation 1, GSEASI is the dependent variable and it represents Ghana Stock Exchange All Share Index (ASI) (measuring stock prices) and the explanatory variables are exchange rate, interest rate and inflation denoted by EXR, INTR and INF accordingly. $\Phi_{0}$ and $\varepsilon_{t}$ are the constant and error terms respectively whereas the $\Phi_{1}, \Phi_{2}$ and $\Phi_{3}$ are the coefficients of exchange rate, interest rate and inflation respectively. The variance equation (equation 2) has one $\mathrm{ARCH}$ term $\left(\varepsilon_{t-1}^{2}\right)$ and one GARCH term $\left(h_{t-1}\right) . h_{t}$ represents the conditional variance whereas $\alpha$ and $\beta$ denote the lagged error term (ARCH effect) and conditional volatility (GARCH effect) respectively. In the variance equation, $\alpha$ and $\beta$ (coefficients) measure the market volatility. A large $\alpha$ indicates that volatility reacts intensely to market movements, whereas a large $\beta$ means that shocks to conditional variance take a long time to die out indicating that volatility is persistent. If summation of $\alpha$ and $\beta$ in the variance equation is close to one (1), then it means that there is high persistence in volatility. In order to satisfy the non-explosiveness conditional variance, the summation of $\alpha$ and $\beta$ must be less than one (1). Further, to satisfy the non-negativity of the conditional variance $\left(h_{t}\right), h_{t-1}, \omega, \alpha$ and $\beta$ must be positive $\left(h_{t-1} \geq 0, \omega \geq 0, \alpha \geq 0, \beta \geq 0\right)$ (Alagidede, 2008).

As mentioned earlier, both the mean and variance equations are jointly estimated using the Bollerslev and Wooldridge (1992) Quasi-maximum likelihood and this requires equation (1) to be plugged into (2); and this yields equation (3).

$$
\begin{gathered}
h_{t}=\omega+\beta h_{t-1}+\alpha \varepsilon_{t-1}^{2}+\Phi_{1} E X R_{t}+ \\
\Phi_{2} I N T R_{t}+\Phi_{3} I N F_{t}
\end{gathered}
$$

where, the variables and the parameters are as explained earlier in equations (1) and (2). The parameters $\Phi_{1}, \Phi_{2}$ and $\Phi_{3}$ measure the effect of exchange rate, interest rate and inflation volatilities on stock prices.

Further, given that time series data is em- 
ployed, the Augmented Dickey Fuller (ADF) test by Dickey and Fuller (1981) and the non-parametric Phillips-Perron (P-P) test by Phillips and Perron (1988) are employed to examine the series properties of the data. In these tests, the null hypothesis of the presence of unit root is tested against the alternative hypothesis of no unit root. Again, in order to ensure the results obtained are not spurious, the study further conducts post estimation diagnostic tests such as normality, heteroscedasticity and serial correlation tests. The normality and heteroscedasticity tests are conducted using the Jarque-Bera and Breusch-Pagan-Godfrey tests respectively. Again, in these tests, the null hypotheses of homoscedasticity and normal distribution are tested against the alternative hypotheses of heteroscedasticity and non-normal distribution accordingly. For the serial correlation, the study examines the standardized residuals squared using the Ljung-Box Q statistic to test the null hypothesis of no autocorrelations of the residuals.

\subsection{Data and variable description}

The study makes use of monthly data spanning the period from January 2000 to October 2016. Data on all the variables: Ghana Stock Exchange (GSE) All Share Index (ASI), exchange rate, interest rate and inflation are obtained from Bank of Ghana.

With regard to the dependent variable (stock prices), it covers all listed financial firms. It is a value weighted index, which comprises all the financial stocks on the GSE. It tracks the performance of financial stocks as they are more sensitive to macroeconomic variables and economic developments. The study measures stock prices using the GSE-ASI. Past studies such as Addo and Sunzuoye (2013) and Kuwornu and Owusu-Nantwi (2011) have also measured stock prices using GSE All Share Index.

With respect to the explanatory variables, the price of the US dollar in Ghanaian Cedi is used as a measure for exchange rate. This measure is used as a result of the predominant use of the dollar relative to other currencies such as euros and pounds in international transactions. The 91-day Treasury bill rate is used as a measure for interest rate. Finally, inflation is measured by the overall consumer price index.

Following theories such as traditional theory of exchange rate and past studies (see, C. Adjasi et al., 2008; Kuwornu \& Owusu-Nantwi, 2011; Olugbenga, 2012), the relationship between exchange rate and stock prices is expected to be either positive or negative. On one hand, domestic currency depreciation (rise in exchange rate) causes imports to be expensive. The high cost of imports leads to higher cost of production and hence a reduction in profit which leads to decline in stock prices. On the other hand, domestic currency depreciation (rise in exchange rate) causes exports to be cheap and hence higher profit which leads to increase in stock prices. Also, based on previous studies (such as Addo \& Sunzuoye, 2013), interest rate is expected to exert negative effect on stock prices. Increase (decrease) in interest rate makes the purchase of government securities attractive (unattractive) and this depreciates (appreciates) the prices of shares. Finally, with regard to inflation and stock prices, a negative relationship is expected. A rise (fall) in inflation causes prices of inputs to be high (low) leading to a rise (fall) in cost of production. The higher (lower) cost of production result in a reduction (increase) in profit which in turn leads to decline (rise) in stock prices.

\section{Results and discussion}

In this section, the descriptive analysis of the variables used is presented in addition to the report and discussion of the estimates from the regression. 


\subsection{Descriptive analysis}

The descriptive statistics of the variables used in the study are reported in Table 2. The standard deviation values from the summary statistics show that the variables deviate much from their mean values. The higher standard deviation values further indicate that there is variation among the variables from their respective means which could be attributed to the volatility nature of the variables.

Table 1: Summary statistics of variables

\begin{tabular}{lcccc}
\hline & ASI & EXR & INTR & INF \\
\hline Mean & 3612.290 & 1.525 & 21.595 & 212.099 \\
Median & 2255.550 & 1.005 & 22.770 & 178.635 \\
Maximum & 10890.800 & 4.187 & 47.000 & 1401.100 \\
Minimum & 739.700 & 0.361 & 9.130 & 53.980 \\
Std. Dev. & 2751.021 & 0.978 & 9.364 & 134.678 \\
Skewness & 0.868 & 1.399 & 0.751 & 3.659 \\
Kurtosis & 2.778 & 3.788 & 3.215 & 31.172 \\
Observation & 202 & 202 & 202 & 202 \\
\hline
\end{tabular}

Source: Authors' computation. Index, Exchange Rate, Interest Rate, Inflation and Standard Deviation, respectively.

\subsection{Unit root}

The results from the ADF test reported in Table 2 indicate that all the variables in the study are stationary at first difference [I(1)]. Similarly, the P-P unit root test (see Table 2 ) shows that all the variables are stationary at first difference $[\mathrm{I}(1)]$ with the exception of inflation (stationary at levels).

\subsection{Test for ARCH effect}

In order to ascertain the suitability of GARCH model, there is the need to test for the presence of ARCH effect. There are various tests which can be used to test for the ARCH effect. In this study, both informal and formal tests are employed to test the ARCH effect. With regard to the informal test, the plot of the series is adopted and the test for autocorrelation in the squares using Ljung-Box test is employed for the formal test. According to Engle (2001), the latter test is able to detect model failures and also Ljung-Box test with
15 lagged autocorrelation is often used.

The results from the plots of the series: stock prices (ASI), exchange rate (EXR), interest rate (INTR) and inflation (INF) are shown in Figure A.1 (see Appendix A). Again, the formal test using the Ljung-Box Q-test is conducted and the results are reported in appendix B. The plots indicate the presence of ARCH effect as there is instability or volatility in the series. Also, the tests for autocorrelation in the squares confirm the presence of ARCH effect since all the Q-statistic values are statistically significant at 1 percent level. This therefore validates the appropriateness of the use of GARCH $(1,1)$ model for the study.

\subsection{Estimated results from GARCH (1, 1) model}

Following the existence of $\mathrm{ARCH}$ effect in the series, the GARCH $(1,1)$ model is estimated. The results from the variance and mean equations are reported in Table 3. The results from the variance equation further confirm the presence of $\mathrm{ARCH}$ effect in the series since the residuals lagged square is statistically significant. Again, the relatively large lagged residuals square coefficient indicates that volatility in the study variables react intensely to market movements. Further, the sum of the coefficients of ARCH and GARCH effects is close to one indicating a high persistence of volatility in the series used. It is also observed that the non-negativity of the conditional variance is satisfied in the study. The study proceeds to discuss the results from the mean equation.

From Table 3, it is observed that there is a positive relationship between exchange rate and stock prices. The coefficient indicates that a 1 percent increase (decrease) in exchange rate increases (decreases) stock prices by 0.16 percent and is statistically significant at 1 percent level. As exchange rate increases (decreases), exports become cheap (expensive) and therefore profit 
Table 2: Unit root test results

\begin{tabular}{lcccccccc}
\hline Variable & \multicolumn{3}{c}{ ADF Test } & \multicolumn{3}{c}{ P-P Test } \\
\hline & \multicolumn{2}{c}{ Level } & \multicolumn{2}{c}{ First Difference } & \multicolumn{3}{c}{ First Difference } \\
\hline ASI & No trend & Trend & No trend & Trend & No trend & Trend & No trend & Trend \\
EXR & -1.729 & -1.531 & $-12.087^{*}$ & $-12.119^{*}$ & -1.835 & -1.833 & $-12.262^{*}$ & $-12.240^{*}$ \\
INTR & -2.028 & 0.018 & $-6.536^{*}$ & $-9.850^{*}$ & 2.112 & -0.016 & $-18.220^{*}$ & $-18.755^{*}$ \\
INF & -2.472 & -2.406 & $-9.622^{*}$ & $-9.637^{*}$ & -2.075 & -1.942 & $-9.853^{*}$ & $-9.855^{*}$ \\
\hline
\end{tabular}

Source: Authors' computation.

Note: * denotes the rejection of the null hypothesis of unit root at 1 percent significance level.

Table 3: Estimated GARCH $(1,1)$ results

\begin{tabular}{lccc}
\hline \multicolumn{4}{c}{ Mean Equation } \\
\hline Variable & Coef. & S.E. & P-value \\
\hline Constant & 9.2425 & 0.3009 & 0.0000 \\
EXR & 0.1585 & 0.0099 & 0.0000 \\
INTR & -0.9670 & 0.0310 & 0.0000 \\
INF & 0.2805 & 0.0431 & 0.0000 \\
\hline \multicolumn{4}{c}{ Variance Equation } \\
\hline Constant & 0.0006 & 0.0003 & 0.0870 \\
RESID(-1)2 & 0.7984 & 0.2115 & 0.0002 \\
GARCH(-1) & 0.2015 & 0.2005 & 0.3125 \\
& & & \\
R-squared & 0.1537 & & \\
Adjusted R-squared & 0.1409 & & \\
Log likelihood & - & & \\
Observations & 34.3994 \\
\hline
\end{tabular}

Source: Authors' estimation.

Note: The estimation is done using natural logarithm of the variables. Coef and S.E. denote coefficient and standard error, respectively.

increases (declines) and stock prices also increase (decrease). The finding is consistent with traditional theory of exchange rate but contradicts findings of studies by C. Adjasi et al. (2008), Kuwornu and Owusu-Nantwi (2011) and Olugbenga (2012).

Further, consistent with the a priori expectation, the study shows a negative relationship between interest rate and stock prices and is significant at 1 percent level. Specifically, the result reveals that a 1 percent increase (decrease) in interest rate leads to 0.97 percent decline (increase) in stock prices. This finding is consistent with the assertion by Rashid (2007) that increment in real interest rates causes a reduction in the present value of a company's future cash flows resulting in a decline in stock prices. Also, the negative result obtained confirms the findings of C. Adjasi et al. (2008), Addo and Sunzuoye (2013) and Kuwornu and
Owusu-Nantwi (2011).

Contrary to our a priori expectation, inflation is revealed to exert a positive effect on stock prices and is significant at 1 percent level. The result specifically indicates that a 1 percent rise (decline) in inflation leads to 0.28 percent increase (fall) in stock prices. The positive and significant relationship could be attributed to the inadequacy of hedging stocks against inflation as reported by Maysami et al. (2005). This finding is consistent with the study by C. Adjasi et al. (2008) and Kuwornu and Owusu-Nantwi (2011).

\subsection{Model diagnostic and reliability test results}

The results from the diagnostic tests are reported in Table 4 . The results show that the estimated model is free from nonnormal distribution and heteroskedasticity problems. This is because the probability values of the test statistic for normality and heteroskedasticity tests are all greater than 0.05. The diagnostic test further indicate that the probability values of the Ljung-Box statistic for the square of residuals are greater than 0.05 indicating the absence of autocorrelation in the square of residuals or insignificant ARCH effects (see Appendix C).

This outcome implies that there is no evidence of linear and non-linear dependence in the standardized residuals and hence the $\operatorname{GARCH}(1,1)$ model used adequately explains the dynamic relationships between exchange rate, interest rate, inflation and stock prices. In all, the diagnostic tests 
Table 4: Diagnostic test results

\begin{tabular}{lcr}
\hline Diagnostic test & $\begin{array}{c}\text { Test } \\
\text { statistic }\end{array}$ & P-value \\
\hline Normality & 1.6644 & 0.4351 \\
Heteroskedasticity & 0.5542 & 0.4575 \\
Correlogram of Standard- & No Serial correlation \\
ised residuals squared (for & & \\
serial correlation) & & \\
\hline Source: Authors' estimation. & &
\end{tabular}

indicate that the results obtained are robust and reliable, hence good for policy purposes.

\section{Concluding remarks}

This study investigates the effect of exchange rate and interest rate volatilities on stock prices using monthly data from January 2000 to October 2016. The ADF and P-P tests are employed to ascertain the stationarity properties of the series. The formal and informal approach to testing of $\mathrm{ARCH}$ effect are employed to ascertain the appropriateness of GARCH the study adopts. Following the confirmation of ARCH effect in the data, the GARCH is employed for the analysis.

The results show that there is a positive and significant relationship between exchange rate, inflation and stock prices. The study also reveals a negative and significant relationship between interest rate and stock prices. Based on the findings, it is concluded that exchange rate volatility exerts a positive effect on stock prices whereas interest rate volatility impacts on stock prices negatively. It is also concluded that inflation exerts a positive effect on stock prices.

The study has policy implications for players and stakeholders in the financial markets. Given the evidence of significant effect of exchange rate volatility on stock prices implies that the trade-off between risk and return can be predicted. Therefore, the present study provides information on how industry players and stakeholders can manage risk to ensure a vibrant financial market. Further, considering the fact that volatility in exchange rate, interest rate and inflation af- fect stock prices as well as activities, there is the need for stakeholders and policymakers to ensure that these variables are stable or the volatilities are minimized in the economy. This will go a long way to enhance the performance of the stock market activities in the country.

\section{References}

Addo, A., \& Sunzuoye, F. (2013). The impact of treasury bill rate and interest rate on the stock market returns: Case of Ghana stock exchange. European Journal of Business and Economics, 8(2), 15-24. doi:10.12955/ejbe.v8i2.378

Adjasi, C., Harvey, S. K., \& Agyapong, D. A. (2008). Effect of exchange rate volatility on the Ghana stock exchange. African Journal of Accounting, Economics, Finance and Banking Research, 3(3), 28-47. https://ssrn.com/ abstract $=1534178$.

Adjasi, C. K., \& Biekpe, N. B. (2005). Stock market returns and exchange rate dynamics in selected African countries: A bivariate analysis. The African Finance Journal, 2(6), 17-28. doi:10.1108/20400701111165623

Aggarwal, R. (2003). Exchange rates and stock prices: A study of the US capital markets under floating exchange rates. Akron Business and Economic Review, 12, 7-12. https://www.researchgate.net/publication/ 284201636_Exchange_rates_and_stock_prices _A_study_of_the_US_capital_markets_under floating_exchange_rates.

Alagidede, P. (2008). Day of the week seasonality in African stock markets. Applied Financial Economics Letters, 4(2), 115-120. doi:10.1080/17446540701537749

Alam, M. M., \& Uddin, M. G. S. (2009). Relationship between interest rate and stock price: empirical evidence from developed and developing countries. International Journal of Business and Management, 4(3), 43-51. https://ssrn.com/ abstract $=2941281$.

Amarasinghe, A. (2015). Dynamic relationship between interest rate and stock price: Empirical evidence from colombo stock exchange. International Journal of Business and Social Science, 6(4), 92-97. http://ijbssnet.com/journal/ index/3104.

Aurangzeb, \& Khola, A. (2012). Effect of time on interest rate, exchange rate and stock prices. International Research Journal of Finance and Economics (86), 63-70.

Aydemir, O., \& Demirhan, E. (2009). The relationship between stock prices and exchange rates: Evidence from Turkey. International Research Journal of Finance and Economics, 23(2), 207-215. https://www.researchgate.net/ 
publication/287875152_The_relationship _between_stock_prices_and_exchange_rates _evidence_from_turkey.

Benita, G., \& Lauterbach, B. (2007). Policy factors and exchange rate volatility. International Research Journal of Finance and Economics, 7(8), 7-23. https://www.biu.ac.il/ soc/sb/stfhome/lauterbah/publications/ Benita_Lauterbach_IRJFE.pdf.

Bollerslev, T., Engle, R. F., \& Wooldridge, J. M. (1988). A capital asset pricing model with timevarying covariances. Journal of Political Economy, 96(1), 116-131. doi:10.1086/261527

Bollerslev, T., \& Wooldridge, J. M. (1992). Quasimaximum likelihood estimation and inference in dynamic models with time-varying covariances. Econometric Reviews, 11(2), 143-172. doi:10.1080/07474939208800229

Caporale, G. M., \& Gil-Alana, L. A. (2016). Interest rate dynamics in Kenya: Commercial banks' rates and the 91-day treasury bill rate. Journal of International Development, 28(2), 214-232. doi:10.1002/jid.3013

Chen, N.-F., Roll, R., \& Ross, S. A. (1986). Economic forces and the stock market. The Journal of Business, 59(3), 383-403.

Connelly, T., Limpaphayom, P., \& Suwannoi, T. (2009). Are insurance firms exposed to foreign exchange rate fluctuations? Evidence from insurers in the Asia-Pacific. Southeast Asian Journal of Economics, 21(1), 2548. https://www.tci-thaijo.org/index.php/ saje/article/view/100192.

Dickey, D. A., \& Fuller, W. A. (1981). Likelihood ratio statistics for autoregressive time series with a unit root. Econometrica, 49(4), 1057-1072. doi: $10.2307 / 1912517$

Dornbusch, R. (1976). Expectations and exchange rate dynamics. Journal of Political Economy, 84(6), 1161-1176. https://www.jstor . org/stable/1831272.

Engle, R. (2001). GARCH 101: The use of ARCH/GARCH models in applied econometrics. Journal of Economic Perspectives, 15(4), 157-168. doi:10.1257/jep.15.4.157

Franck, P., \& Young, A. (1972). Stock price reaction of multinational firms to exchange realignments. Financial Management, 1(3), 66-73. doi: $10.2307 / 3665374$

Frankel, J. A. (1979). On the mark: A theory of floating exchange rates based on real interest differentials. The American Economic Review, 69(4), 610-622. https://www.jstor.org/ stable/1808707.

Furman, J., Stiglitz, J. E., Bosworth, B. P., \& Radelet, S. (1998). Economic crises: Evidence and insights from East Asia. Brook ings Papers on Economic Activity(2), 1-135. doi: $10.2307 / 2534693$

Haughton, A. Y., \& Iglesias, E. M. (2017). Exchange rate movements, stock prices and volatility in the caribbean and latin america. International Journal of Economics and Financial
Issues, 7(2), 437-447. https://dergipark.org .tr/en/pub/ijefi/issue/32035/354508.

Hyde, S. (2007). The response of industry stock returns to market, exchange rate and interest rate risks. Managerial Finance, 33(9), 693-709. doi:10.1108/03074350710776244

Iqbal, J., \& Haider, A. (2005). Arbitrage pricing theory: Evidence from an emerging stock market. Lahore Journal of Economics, 10(1), 123-139. doi:10.35536/lje.2005.v10.i1.a8

Joseph, N. L. (2002). Modelling the impacts of interest rate and exchange rate changes on uk stock returns. Derivatives Use, Trading and Regulation, 7(4), 306-323.

Kuwornu, J. K. M., \& Owusu-Nantwi, V. (2011). Macroeconomic variables and stock market returns: Full information maximum likelihood estimation. Research Journal of Finance and Accounting, 2(4), 49-63. https://www.iiste.org/ Journals/index . php/RJFA/article/view/552.

Kwofie, C., \& Ansah, R. K. (2018). A study of the effect of inflation and exchange rate on stock market returns in Ghana. International Journal of Mathematics and Mathematical Sciences, 2018(7016792). doi:10.1155/2018/7016792

Mathieson, G., \& Moles, P. (1998). Company value and economic currency risk: an empirical study of uk-listed importers and exporters. Journal of International Business Studies, 1-29.

Maysami, R. C., Howe, L. C., \& Hamzah, M. A. (2005). Relationship between macroeconomic variables and stock market indices: Cointegration evidence from stock exchange of Singapore's all-S sector indices. Jurnal Pengurusan (UKM Journal of Management), 24, 47-76. http://ejournal .ukm.my/pengurusan/article/view/1454.

Mouna, A., \& Anis, J. (2016). Market, interest rate, and exchange rate risk effects on financial stock returns during the financial crisis: AGARCH-M approach. Cogent Economics \& Finance, 4(1), 1125332. doi:10.1080/23322039.2015.1125332

Muhammad, N., \& Rasheed, A. (2002). Stock prices and exchange rates: Are they related? evidence from south asian countries [with comments]. The Pakistan Development Review, 41(4), 535-550. https://www.jstor.org/stable/41263367.

Okpara, G. C., \& Odionye, J. C. (2012). Analysis of the relationship between exchange rate and stock prices: Evidence from Nigeria. International Journal of Current Research, 4(3), 175183. http://journalcra.com/sites/default/ files/issue-pdf/1660.pdf.

Olugbenga, A. A. (2012). Exchange rate volatility and stock market behaviour: The Nigerian experience. European Journal of Business and Management, 4 (5), 31-39. https://www.iiste.org/ Journals/index.php/EJBM/article/view/1504.

Opoku-Agyemang, B., Ofori-Abebrese, G., \& Korankye, B. (2016). Analysis of interest rate and stock price in africa: Case study of ghanaian listed firms. International Journal of Science and Research, 5(10), 1582-1587. 
https://pdfs.semanticscholar.org/1171/ e76902a25779d522440625a21f9712115ef5.pdf.

Phillips, P. C. B., \& Perron, P. (1988). Testing for a unit root in time series regression. Biometrika, 75(2), 335-346. doi:10.1093/biomet/75.2.335

Randal, J., Xue, S., \& Han, C. (2008). Estimating short term exchange rate exposure for new zealand firms. http://www.nzae.org.nz/wp -content/uploads/2011/08/nr1215397358.pdf.

Rashid, A. (2007). Exchange rates or stock prices, what causes what: A firm level empirical investigation (MPRA Paper No. 27209). https:// mpra.ub.uni-muenchen.de/27209/.

Samarakoon, L. P., Hasan, T., \& Hasan, S. (1999). Stock price behavior in a less developed market: Evidence from Sri Lanka. Journal of $A p$ plied Business Research, 16(02), 15-23. https:// ssrn. com/abstract $=1552826$.

Sargent, T., \& Wallace, N. (1981). Some unpleasant monetarist arithmetic. Federal Reserve Bank of Minneapolis Quarterly Review, 5(3), 1-17. https://www.minneapolisfed.org/ research/qr/qr531.pdf.

Sichoongwe, K. (2016). Effects of exchange rate volatility on the stock market: The Zambian experience. Journal of Economics and Sustainable Development, 7(4), 114119. https://iiste.org/Journals/index.php/ JEDS/article/view/29050.

Solnik, B. (1987). Using financial prices to test exchange rate models: A note. The Journal of Finance, 42(1), 141-149. doi:10.2307/2328424

Suriani, S., Kumar, M. D., Jamil, F., \& Muneer, S. (2015). Impact of exchange rate on stock market. International Journal of Economics and Financial Issues, 5(1), 385388. http://www.econjournals.com/index.php/ ijefi/article/view/1510.

Vaz, J., Ariff, M., \& Brooks, R. (2008). The effect of interest rate changes on bank stock returns. Investment Management and Financial Innovations, 5(4), 221-236. https:// businessperspectives.org/images/pdf/ applications/publishing/templates/article/ assets/2451/imfi_en_2008_04_cont_Vaz.pdf.

Zhao, H. (2010). Dynamic relationship between exchange rate and stock price: Evidence from china. Research in International Business and Finance, 24(2), 103-112. doi:10.1016/j.ribaf.2009.09.001 


\section{Appendices}

\section{Appendix A.}

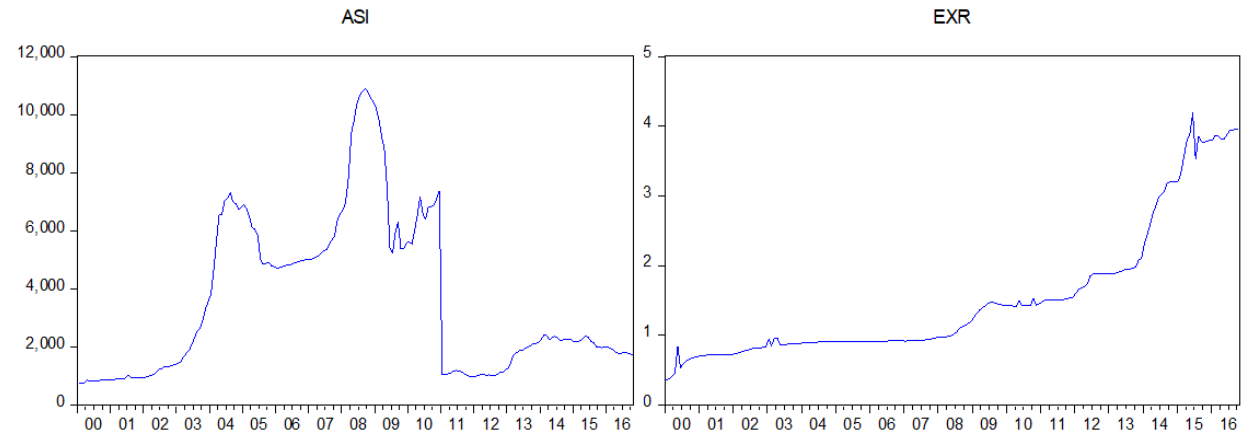

INTR

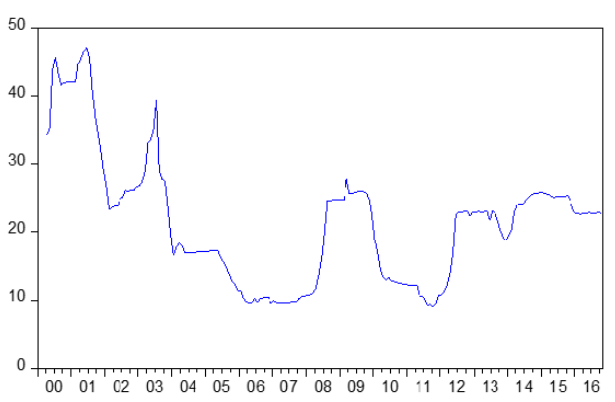

$\mathbb{N} F$

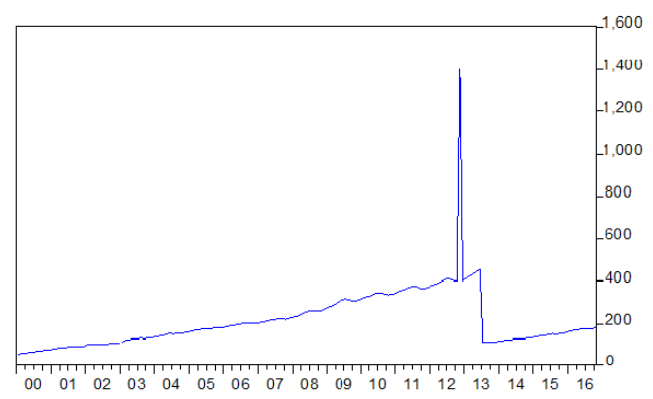

Figure A.1: Plot of the series for the determination of ARCH effect

Source: Authors' construction.

\section{Appendix B.}

Table B.1: Test for autocorrelation in the All Share Index square

\begin{tabular}{lcccc}
\hline & $\begin{array}{c}\text { Autocorre- } \\
\text { lation }\end{array}$ & $\begin{array}{c}\text { Partial } \\
\text { Correlation }\end{array}$ & Q-Stat & Prob \\
\hline 1 & 0.976 & 0.976 & 195.46 & 0.000 \\
2 & 0.940 & -0.290 & 377.48 & 0.000 \\
3 & 0.897 & -0.089 & 544.07 & 0.000 \\
4 & 0.848 & -0.111 & 693.66 & 0.000 \\
5 & 0.791 & -0.142 & 824.57 & 0.000 \\
6 & 0.732 & -0.006 & 937.20 & 0.000 \\
7 & 0.671 & -0.036 & 1032.4 & 0.000 \\
8 & 0.607 & -0.086 & 1110.8 & 0.000 \\
9 & 0.546 & 0.069 & 1174.4 & 0.000 \\
10 & 0.490 & 0.063 & 1225.9 & 0.000 \\
11 & 0.443 & 0.124 & 1268.2 & 0.000 \\
12 & 0.403 & 0.071 & 1303.5 & 0.000 \\
13 & 0.371 & 0.012 & 1333.4 & 0.000 \\
14 & 0.345 & 0.052 & 1359.6 & 0.000 \\
15 & 0.329 & 0.063 & 1383.4 & 0.000 \\
\hline Source: & Authors' estimation. & &
\end{tabular}


Table B.2: Test for autocorrelation in the Exchange Rate square

\begin{tabular}{lcccc}
\hline & $\begin{array}{c}\text { Autocorre- } \\
\text { lation }\end{array}$ & $\begin{array}{c}\text { Partial } \\
\text { Correlation }\end{array}$ & Q-Stat & Prob \\
\hline 1 & 0.972 & 0.972 & 193.82 & 0.000 \\
2 & 0.949 & 0.063 & 379.34 & 0.000 \\
3 & 0.922 & -0.071 & 555.33 & 0.000 \\
4 & 0.895 & -0.024 & 721.99 & 0.000 \\
5 & 0.870 & 0.025 & 880.27 & 0.000 \\
6 & 0.846 & 0.008 & 1030.6 & 0.000 \\
7 & 0.820 & -0.040 & 1172.8 & 0.000 \\
8 & 0.794 & -0.038 & 1306.6 & 0.000 \\
9 & 0.765 & -0.047 & 1431.7 & 0.000 \\
10 & 0.737 & -0.013 & 1548.3 & 0.000 \\
11 & 0.709 & -0.020 & 1656.8 & 0.000 \\
12 & 0.680 & -0.035 & 1757.0 & 0.000 \\
13 & 0.650 & -0.027 & 1849.2 & 0.000 \\
14 & 0.620 & -0.038 & 1933.3 & 0.000 \\
15 & 0.586 & -0.074 & 2009.0 & 0.000 \\
\hline
\end{tabular}

Table B.3: Test for autocorrelation in the Interest Rate square

\begin{tabular}{lcccc}
\hline & $\begin{array}{c}\text { Autocorre- } \\
\text { lation }\end{array}$ & $\begin{array}{c}\text { Partial } \\
\text { Correlation }\end{array}$ & Q-Stat & Prob \\
\hline 1 & 0.974 & 0.974 & 194.42 & 0.000 \\
2 & 0.935 & -0.257 & 374.56 & 0.000 \\
3 & 0.893 & -0.024 & 539.76 & 0.000 \\
4 & 0.845 & -0.130 & 688.49 & 0.000 \\
5 & 0.796 & -0.003 & 821.07 & 0.000 \\
6 & 0.740 & -0.172 & 936.12 & 0.000 \\
7 & 0.685 & 0.082 & 1035.3 & 0.000 \\
8 & 0.637 & 0.065 & 1121.4 & 0.000 \\
9 & 0.593 & 0.046 & 1196.4 & 0.000 \\
10 & 0.548 & -0.105 & 1260.9 & 0.000 \\
11 & 0.504 & 0.005 & 1315.8 & 0.000 \\
12 & 0.458 & -0.120 & 1361.4 & 0.000 \\
13 & 0.411 & -0.042 & 1398.2 & 0.000 \\
14 & 0.366 & -0.002 & 1427.6 & 0.000 \\
15 & 0.326 & 0.120 & 1451.0 & 0.000 \\
\hline
\end{tabular}

Table B.4: Test for autocorrelation in the Inflation square

\begin{tabular}{lcccc}
\hline & $\begin{array}{c}\text { Autocorre- } \\
\text { lation }\end{array}$ & $\begin{array}{c}\text { Partial } \\
\text { Correlation }\end{array}$ & Q-Stat & Prob \\
\hline 1 & 0.215 & 0.215 & 9.4475 & 0.002 \\
2 & 0.214 & 0.176 & 18.880 & 0.000 \\
3 & 0.215 & 0.151 & 28.474 & 0.000 \\
4 & 0.214 & 0.130 & 38.041 & 0.000 \\
5 & 0.212 & 0.112 & 47.437 & 0.000 \\
6 & 0.210 & 0.099 & 56.686 & 0.000 \\
7 & 0.206 & 0.086 & 65.693 & 0.000 \\
8 & 0.117 & -0.025 & 68.584 & 0.000 \\
9 & 0.112 & -0.017 & 71.243 & 0.000 \\
10 & 0.106 & -0.011 & 73.658 & 0.000 \\
11 & 0.100 & -0.004 & 75.806 & 0.000 \\
12 & 0.094 & 0.003 & 77.737 & 0.000 \\
13 & 0.090 & 0.011 & 79.493 & 0.000 \\
14 & 0.087 & 0.020 & 81.151 & 0.000 \\
15 & 0.085 & 0.028 & 82.742 & 0.000 \\
\hline
\end{tabular}

Source: Authors' estimation. 


\section{Appendix C.}

Table C.1: Test for autocorrelation in the standardized residuals squared

\begin{tabular}{lcccc}
\hline & $\begin{array}{c}\text { Autocorre- } \\
\text { lation }\end{array}$ & $\begin{array}{c}\text { Partial } \\
\text { Correlation }\end{array}$ & Q-Stat & Prob* \\
\hline 1 & 0.053 & 0.053 & 0.5692 & 0.451 \\
2 & 0.062 & 0.060 & 1.3674 & 0.505 \\
3 & 0.036 & 0.030 & 1.6431 & 0.650 \\
4 & -0.036 & -0.043 & 1.9141 & 0.752 \\
5 & -0.052 & -0.053 & 2.4838 & 0.779 \\
6 & -0.035 & -0.026 & 2.7346 & 0.841 \\
7 & -0.027 & -0.015 & 2.8908 & 0.895 \\
8 & -0.044 & -0.037 & 3.3105 & 0.913 \\
9 & -0.057 & -0.053 & 3.9966 & 0.912 \\
10 & 0.052 & 0.060 & 4.5830 & 0.917 \\
11 & -0.030 & -0.031 & 4.7818 & 0.941 \\
12 & -0.033 & -0.040 & 5.0149 & 0.957 \\
13 & -0.055 & -0.063 & 5.6810 & 0.957 \\
14 & -0.017 & -0.009 & 5.7413 & 0.973 \\
15 & -0.063 & -0.055 & 6.6167 & 0.967 \\
\hline
\end{tabular}

